освіченого професійного педагога. Незважаючи на митарства, злидні, труднощі, які пройшли вчителі і народна школа загалом, можна сказати про те, що в XIX ст. було закладено фундамент організації роботи 3 педагогічними кадрами. Вагомий внесок у забезпечення діяльності вчителів народних шкіл другої половини XIX ст. зробили земства губернії.

\title{
Література
}

1. Освіта на Миколаївщині у XX-XX ст. (Історичні нариси). - Миколаїв : Вид-во УДМТУ. 2. Демков М. И. Курс педагогики. - 4.2: Теория и практика воспитания. - Москва Петроград. -Изд. В. В., 1915. - 366 с. 3. Каптерев П. Ф. История русской педагогики. Петроград: Земля, 1915. - 746 с. 4. Материалы по делу народного образования в Херсонском уезде, извлеченные из дела земства членом Херсонских уездных - училищного совета и земской управы Герцешлтейном и им же составленный обзор деятельности земства Херсонского уезда в деле народного образования в период времени от открытия земских учреждений до настоящего времени. 1865-1874.- Херсон: Типография И. О. Ващенко, 1874. - 637 с. 5. Учебное заведение Одесского учебного округа, состоящее в ведении дирекций народных училищ. - Вып. 3: Таврическая дирекция. - Одесса, 1891.- С. 128. 6. Сборник Херсонского земства. -1899. - № 5 (май). - Херсон, 1899. -327 с. 7. Сборник Херсонского земства. - 1892. - № 12 (декабрь). - Херсон. - 1892. - 440 с. 8. Державний архів Одеської області, ф. Р-91, оп.1, спр. 52, 17 с. 9. Херсонские епархиальные ведомости. - 1886. № 7. - С. 343; - № 9. - 429 с. 10. Сборник Херсонского земства. -1898. - №8 (август). Херсон, 1898. - 159 с. 11. Сборник Херсонского земства. - 1896. - № 10 (октябрь). - Херсон. 1896. - 509c. 12. Народное образование в России с 60-х годов XIX века / сост. Н. В. Чехов. Москва. - По 1912. - 224 с. 13. Стоюнин В. Я. Педагогическое сочинение. - СПб : Тип. М. М. Стасюлевича, 1911. -488 с.

УДК 378.147

Тетяна Мотуз

\section{ФОРМУВАННЯ ІДЕЙ ТОЛЕРАНТНОСТІ В ПЕДАГОГІЧНІЙ ДУМЦІ УКРАЇНИ: ДЖЕРЕЛОЗНАВЧИЙ АСПЕКТ}

Мотуз Т. В. Формування ідей толерантності в педагогічній думці України: джерелознавчий аспект.

У статті здійснено аналітичний огляд та класифікацію джерелознавчої бази досліджень історії розвитку ідеї толерантності в педагогічній думці України. Виявлені джерела систематизовано в чотири групи, що представляють послідовність наукового розроблення досліджуваної проблеми. Репрезентативність сформованої джерельної бази обгрунтовано на основі джерелознавчого аналізу й синтезу з урахуванням соціокультурного контексту.

Ключові слова: історичне джерело, педагогічне джерело, джерела актованого характеру, науково-педагогічні джерела, толерантність, класифікація.

Мотуз Т. В. Формирование идей толерантности в педагогической мысли украины: источниковедческий аспект.

В статье осуществлен аналитический обзор и классификация источниковедческой базы исследований истории развития идеи толерантности в педагогической мысли Украины. Выявленные источники систематизированы в четыре группы, представляющие последовательность научной разработки исследуемой проблемы: 1) источники актированного характера (законодательные материалы международного, всеукраинского, регионального уровней: декларации, законы, постановления, приказы и др.); 2) научнопедагогические источники (монографии, статьи, исторические исследования, диссертации на соискание ученой степени доктора и кандидата наук); 3) методическая литература (учебные пособия, рекомендации, разработанные педагогическими коллективами учебных заведений разных типов, обобщение опыта, отчеты, материалы съездов, конференций) 4) источники 
личного происхождения: мемуары и произведения художественной литературы. Репрезентативность сложившейся источниковой базы обоснован источниковедческим анализом и синтезом с учетом социокультурного контекста.

Ключевые слова: исторический источник, педагогический источник, источники актированного характера, научно-педагогические источники, толерантность, классификация.

Motuz T. V. Forming the ideas of tolerance in educational thought of Ukraine: the source studies aspect.

An analytical review and classification of source database of research of ideas of tolerance in educational thought of Ukraine are given in this article. The sources are identified and systematized in four groups, and represent the sequence of scientific development of the research problem.They are normative sources (legislative materials of international, national, regional levels: declarations, laws, resolutions, orders etc.); scientific-pedagogical sources (monographs, articles, historical researches, dissertations for the doctor's and candidate degree); methodical literature (tutorials, recommendations, which are developed by pedagogical staffs of educational institutions of different types, generalization of experience, reports, materials of congresses, conferences); sources of personal origin: memoirs (memories and autobiographies) and works of fiction. Representation of formed sources is based on source-grounded analysis and synthesis taking into accounts the socio-cultural context.

We were guided by the following principles to select sources for analysis: authenticity (information contained in selected sources is not only versatile and complete, but authentic); complementarity (primary data coming from different sources must be mutually complemented, varied and most fully reflect all aspects of the research subject); consistency (to make theoretical generalizations sources should enable systematic coverage of the most significant facts).

The complex of historical and educational resources and literature, which are worked out in the research process, includes all the possible ways of obtaining information that enables to make the system analysis and generalization of the research problem. The analysis of studied sources shows that they are quite reliable and sufficient for the theme.

The systematization of source database of the research the history of ideas of tolerance in educational thought of Ukraine, presented in article, allows considering the development of various aspects of the research problem in dynamics from a theoretical study to practical implementation.

Key words: historical source, pedagogical source, normative sources, scientific-pedagogical sources, tolerance, classification.

Концепт «толерантність» для науки, зокрема педагогічної, є новим. Він сформувався в середині XX століття як розгорнуте розуміння сутності понять «милосердя», «терпимість» і подібних. Розвиток концепту і його широке застосування в освітній діяльності пов'язані 3 розвитком глобальних відносин і все більшою прозорістю кордонів у всьому світі. Унаслідок революційних перетворень, численних реформ освітніх систем принципи толерантності стали невід'ємною частиною та необхідною умовою організації освітнього процесу. Система освіти має значний потенціал для виховання толерантності, оскільки вона впливає на людину вже з дитинства, формуючи доброзичливість, інтерес до відмінностей і здатність оцінювати людину неупереджено.

Концентрація зусиль науковців та педагогів-практиків на розв'язання зазначеної соціально-педагогічної проблеми відкриває можливість більш глибокої сучасної інтерпретації принципів педагогіки толерантності, упровадження особистісно зорієнтованої освіти, що забезпечують гармонію загальнолюдської, міжнаціональної, національної та індивідуально-особистісної культури.

Попри значний науковий доробок педагогів щодо проблеми толерантності, можемо стверджувати, що на сьогодні проблема джерелознавчої бази досліджень історії розвитку ідеї толерантності у вітчизняній педагогічній думці не отримала належного обгрунтування.

Проблема відбору, встановлення достовірності та точності історичних джерел, а 
також методи обробки й аналізу відомостей, що містяться в них, розробляються джерелознавством - спеціальною галуззю історичних знань, наукою про історичні джерела, теорію і практику їх використання в дослідженнях. У сучасному підручнику «Історичне джерелознавство» Я. Калакура подає таке визначення історичного джерела: «Історичне джерело - це носій історичної інформації, що виник як продукт розвитку природи і людини й відбиває той чи той бік людської діяльності» [5, с. 28].

Типами історичних джерел називають ті їх групи, що мають споріднений спосіб передачі відомостей або близькі за змістом, формою і походженням. Визначають такі типи джерел: а) речові; б) словесні (вербальні); в) зображальні; г) звукові (фонічні); д) поведінкові. Класифікацію за авторством застосовують як до словесних, так і до речових, зображальних, конвенціональних, поведінкових, звукових джерел, однак у кожному окремому випадку враховуються специфіка створення джерела і форма передачі інформації. У проблемнотематичних дослідженнях, в історико-краєзнавчій роботі, в навчальному процесі нерідко застосовується групування джерел за хронологічно-географічною ознакою. При цьому враховуються два основні критерії:

1) епоха або історичний період виникнення джерела;

2) місце створення джерела (країна, регіон, місцевість) [5, с. 47].

Педагогічні джерела є емпіричною основою пізнання історико-педагогічної дійсності. Педагогічний джерело - це різновид джерела історичного, оскільки методологія пізнання реальності минулого постає в якості загальної основи для всіх галузей наукового історичного знання.

Радянський науковець Д. Раскін визначає історико-педагогічне джерело як «продукт соціальної діяльності, що містить у вигляді певної знакової системи інформацію про суспільні процеси виховання та навчання, закріплює цю інформацію та володіє потенційними умовами для включення цієї інформації в систему історико-педагогічних знань» [9, с. 91].

Особливості вивчення педагогічних фактів полягають у тому, що їх не можна безпосередньо спостерігати та експериментально відтворити. Факти минулої педагогічної дійсності пізнаються опосередковано, через джерела. Історики педагогіки визнають різноманіття видів педагогічних джерел, яке, у свою чергу, породжене різноманіттям форм соціальнопедагогічної діяльності людей і відносин між ними. Спроби класифікувати джерельну базу історико-педагогічної науки робили українські науковці Л. Голубнича [2], Н. Гупан [3], С. Лобода [7], О. Петренко [8], Н. Сейко [11], О. Сухомлинська [12] та ін. Праці згаданих вище авторів демонструють той факт, що не існує єдиної класифікації історико-педагогічних джерел. Здійснюючи поділ на групи, дослідники беруть за основу такі показники: час і місце написання джерел, місце зберігання, рівень узагальнення фактологічного матеріалу, близькість до відображуваних подій, предмет вивчення тощо.

У роботі «Класифікація історико-педагогічних джерел» (1989 р.) письмові джерела Д. Раскін поділяє на роди, види i, відповідно, підвиди. Документальні джерела як рід представлені чотирма видами: актові, діловодні, статистичні та картографічні. Розповідні джерела як рід представлені п'ятьма видами: особисті, художні, публіцистичні, історичні, наукові. Дидактичні джерела - це документація навчального процесу (підручники, програми, навчальні плани, класні журнали, учнівські роботи тощо) [10]. Вітчизняний дослідник Н. Гупан [3] запропонував класифікувати історико-педагогічні джерела за проблемнотематичним, хронологічним і персоніфікованим підходами [3, с. 18].

Mema cmammi - здійснити аналітичний огляд та класифікацію джерелознавчої бази досліджень історії розвитку ідеї толерантності в педагогічній думці України.

Початковий етап роботи 3 дослідження процесу розвитку ідеї толерантності учнівської молоді у вітчизняній педагогічний думці другої половини XX - початку XXI століть пов'язаний з визначенням кола історико-педагогічних джерел, необхідних для виконання поставлених завдань.

Задля грунтовного дослідження проблеми розвитку ідеї толерантності учнівської 
молоді у вітчизняній педагогічний думці другої половини XX- початку XXI століть, спираючись на класифікації, запропоновані вітчизняними дослідниками, зокрема Л. Голубничою [2], Н. Гупаном [3], О. Петренко [8], О. Сухомлинською [12], розподілили джерела дослідження на такі групи: 1) джерела актованого характеру (законодавчі матеріали міжнародного, всеукраїнського, регіонального рівнів: декларації, закони, постанови, накази та ін.); 2) науково-педагогічні джерела (монографії, статті, історичні дослідження, дисертації на здобуття наукового ступеня доктора та кандидата наук); 3) методична література (навчальні посібники, рекомендації, що розроблялися педагогічними колективами закладів освіти різних типів, узагальнення досвіду, звіти, матеріали з’їздів, конференцій). Значущість джерел цієї групи, як і попередньої, полягає в тому, що в них були зосереджені основні відомості про норми всього навчально-виховного процесу, а відповідно до них давалися рекомендації та вказівки щодо його поліпшення в окремих навчальних закладах; 4) джерела особистого походження: мемуари (мемуари-спогади і мемуари-автобіографії) i твори художньої літератури, у яких найбільш послідовно втілено процес розвитку ідеї толерантності, становлення міжособистісних стосунків.

Відбираючи джерела для проведення аналізу, ми керувалися такими принципами: достовірності (інформація, яка містяться у відібраних джерелах, має бути не тільки багатогранною й повною, а й достовірною); взаємодоповнення (первинні дані, які надходять 3 різних джерел, мають взаємно доповнюватись, бути різноманітними та якнайповніше відображати всі аспекти предмета дослідження); системності (для здійснення теоретичних узагальнень джерела мають надавати можливість системного охоплення найбільш істотних фактів).

Комплекс історико-педагогічних джерел та літератури, які опрацьовано у процесі дослідження, містить усі можливі напрямки отримання інформації, що дає змогу робити системний аналіз та узагальнення 3 досліджуваної проблеми. Аналіз вивчених джерел свідчить, що вони цілком достовірні і достатні для розкриття теми.

Аналізуючи джерела першої групи (джерела актованого характеру) ми звертали увагу на те, як ідея толерантності зафіксована і відображена у нормативних документах міжнародного, всеукраїнського, регіонального рівнів, а також на місце толерантності в актованих документах вітчизняної системи освіти II половини XX - початку XXI століття.

Серед документів міжнародного рівня, в основу яких покладено принципи демократії, рівноправ'я, взаємоповаги та рівності у різних сферах суспільного життя, слід виокремити Declaration of principles on tolerance/ Декларацію принципів толерантності (Резолюція Генеральної конференції ЮНЕСКО 16.11.1995 р.), Convention on the Elimination of All Forms of Discrimination Against Women / Конвенцію ООН про ліквідацію всіх форм дискримінації щодо жінок (Факультативний протокол 995_794 від 06.10.1999р.), International Convention on the Elimination of All Forms of Racial Discrimination / Міжнародну Конвенцію про ліквідацію всіх форм расової дискримінації (Генеральна Асамблея ООН від 21.12.1965р.), Declaration on the Rights of Persons Belonging to National or Ethnic, Religious and Linguistic Minorities / Декларацію про права осіб, що належать до національних або етнічних, релігійних та мовних меншин (Генеральна Асамблея ООН від 18.12.1992р.), The UN Convention on the rights of the child / Конвенцію ООН про права дитини (Генеральна Асамблея ООН від 21.12.1995 р.) та ін.

Головним актованим джерелом міжнародного рівня, що має велике значення для нашого дослідження, $\epsilon$ Declaration of principles on tolerance / Декларація принципів толерантності (далі - Декларація) [4], затверджена Резолюцією Генеральної конференції ЮНЕСКО 16 листопада 1995 року. У ній держави - учасниці Організації Об’єднаних Націй 3 питань освіти, науки і культури, визначили, що толерантність $є$ не тільки найважливішим принципом, а й необхідною умовою миру і соціально-економічного розвитку всіх народів [4]. Важливе значення для досліджень у галузі суспільно-гуманітарних наук, у тому числі у педагогіці, $є$ те, що в Декларації подається чітке визначення терміна «толерантність». У цьому документі концепт «толерантність» має кілька трактувань: 1) повага, прийняття та розуміння різноманіття культур нашого світу, наших форм самовираження і способів вияву 
людської індивідуальності; 2) чеснота, яка робить можливим досягнення миру і сприяє заміні культури війни культурою миру; 3) активне ставлення, що формується на основі визнання універсальних прав і основних свобод людини; 4) відмова від абсолютизації істини та затвердження норм, встановлених в міжнародних правових актах у галузі прав людини [4]. У Декларації актуалізовано питання виховання толерантності як особистісної якості, людської чесноти і найбільш ефективного засобу попередження насильства й нетерпимості. Головним інструментом виховання толерантності декларація визначає систему освіти. У ст. 4 документа обгрунтовується необхідність виховання в дусі терпимості, що повинно сприяти формуванню в молоді навичок незалежного мислення, критичного осмислення суджень, що базуються на моральних цінностях [4].

Ідеї толерантності, гуманізму, демократії знайшли своє відображення у низці нормативних документів сфери освіти, серед яких Закони України «Про освіту» (2016), «Про загальну середню освіту» (1999), Національна доктрина розвитку освіти (Указ Президента України від 17.04.2002 р. № 347/2002), Концепція виховання дітей та молоді в національній системі освіти (колегія Міністерства освіти і науки України 28.12.1996 р.), Положення про класного керівника навчального закладу системи загальної середньої освіти (наказ Міністерства освіти і науки України № 434 від 06.09.2000р.), Основні оріснтири виховання учнів 1-11 класів загальноосвітніх навчальних закладів (наказ Міністерства освіти і науки, молоді та спорту України від 31.10.2011p. №1243), Концепція національного виховання (схвалена Всеукраїнською педагогічною радою працівників освіти 30 червня 1994 року), Концепція національно-патріотичного виховання дітей і молоді (наказ Міністерства освіти і науки України № 641 від 16.06.2015 р.) та ін. Звернення до цих документів дало нам змогу систематизувати та узагальнити державні вимоги до системи освіти щодо формування толерантності підростаючого покоління, демократизації освітнього процесу, а також встановити залежність практики виховання у вітчизняних навчальних закладах від вектору розвитку державної політики в галузі освіти.

3-поміж другої групи джерел (науково-педагогічні джерела) перше місце за кількістю посідають статті в педагогічних часописах. У хронологічних межах нашого дослідження і до цього часу стаття є найбільш поширеним комунікаційним елементом у науці, відповідно найбільш поширеною комунікаційною структурою - науковий журнал. Наукові часописи $\epsilon$ одночасно і головним засобом повідомлення про нові досягнення науки, нові знання, i «фундаментальним архівним сховищем» перевірених і визнаних наукових результатів, інструментом, за допомогою якого дослідники створюють свою професійну репутацію [6].

Статті, опубліковані в педагогічних журналах, є цінними для дослідження історії розвитку ідеї толерантності. Аналіз їх змісту дав нам змогу отримати інформацію про те, на яких напрямках у той чи той період часу концентрувалася увага педагогів-науковців i практиків, як здійснювалися дослідження і як їх результати впливали на освітню практику, хто 3 українських науковців зробив найбільший внесок у розвиток ідеї толерантності в означений термін. Крім того, кількість і якість матеріалів, опублікованих у педагогічних часописах протягом другої половини XX - початку XXI століття, були для нас й індикатором розвитку ідеї толерантності, показником зміни інтересу науковців до толерантності як педагогічного концепту.

Аналізуючи статті у науково-педагогічних виданнях II половини XX - початку XXI ст., ми враховували такі їх особливості: через наукові статті повідомляються результати важливих досліджень; стаття робить наукову інформацію доступною широкому загалу; опублікована стаття $є$ завершальним етапом певної частини наукового дослідження; стаття $є$ засобом передачі наукових знань у часі й просторі; наукові публікації відбивають історію розвитку науки, відображають сучасний стан їі досягнень, а також спонукають до подальшого прогресу; на інформацію, подану в статті, можна посилатись як на достовірну та коректну, адже наукові статті проходять процедури рецензування та редагування науковцями відповідних галузей.

Важливим для нас було визначити коло науково-педагогічних журналів II половини 
XX-початку XXI ст., які ми використовували як джерела для аналізу розвитку ідеї толерантності у зазначений період. Чільне місце серед вітчизняних науково-педагогічних часописів належить журналу «Радянська школа» (з 1991 року - «Рідна школа»). Статті, опубліковані в «Радянській школі», є науковими та високої якості, адже публікації завжди передувала процедура відбору, рецензування та редагування матеріалів. У межах нашого дослідження журнал мав значний наклад і був популярним як серед науковців, так і серед педагогів-практиків. Окрім журналу «Радянська школа», ми аналізували матеріали вісника АПН України «Педагогіка і психологія», «Шлях освіти», «Педагогіка толерантності» та ін.

Особливу увагу під час проведення дослідження ми приділили такому виду науковопедагогічних джерел, як дисертації на здобуття наукового ступеню кандидата й доктора педагогічних наук. Дисертація, особливо докторська, $\epsilon$ значним внеском у розвиток наукового знання. Аналізуючи дисертації, ми враховували як кількісні показники у той чи той період часу, так і якісні (напрям досліджень, новизна, значення для розвитку науки тощо).

Термін «толерантність» у тематиці дисертаційних робіт з'явився лише на початку XXI століття, що пов'язано 3 тим, що означений концепт порівняно новий для вітчизняної педагогічної науки. Проте у II половині XX століття активно проводилися дослідження та захищалися дисертації 3 питань, дотичних до тематики толерантності, таких, як інтернаціоналізм, гуманізм, демократизація освітнього процесу тощо.

Зважаючи на те, що концепт «толерантність» є міждисциплінарним, тобто таким, що досліджується різними науками, цінними для нашого дослідження були наукові розвідки 3 філософії, психології, соціології. Так, положення докторської дисертації Г. Бардієр розкриває проблематику класифікації видів толерантності / інтолерантності (міжвікова, гендерна, міжособистісна, міжетнічна, міжкультурна, міжконфесійна, професійна, управлінська, соціально-економічна і політична), а також погляди на їі структуру [1]. Використані у дослідженні наукові роботи Р. Валітової, П. Кінга, В. Лекторського, М. Мацковського та ін.) надали можливість виокремити наукові напрямки, які досліджують різні аспекти проблеми толерантності (аксіологічний, акмеологічний, гносеологічний), зрозуміти природу феномену «толерантність» 3 точки зору філософії й соціології та передумови його інтеграції в систему педагогічних наук.

Для нашого дослідження вагомими були дисертаційні роботи з педагогіки щодо місця толерантності в освітньому процесі за спец. 13.00.07- «Теорія і методика виховання» (О. Андрійчук, Н. Барбелко, Л. Бернадська, Т. Білоус, О. Вербицький, О. Волошина, Т. Гурова, М. Карандаш, Е. Койкова, О. Матієнко, О. Столяренко та ін.), 13.00.04 - «Теорія і методика професійної освіти» (М. Андреєв, Н. Бирко, І. Залєсова, А. Зінченко, Ю. Ірхіна, Ю. Костелянець, Р. Костенко, О. Орловська, Д. Пащенко, Ю. Тодорцева, та ін.), 13.00.01 «Загальна педагогіка, історія педагогіки» (С. Авраменко, О. Зарівна та ін.) 13.00.05 «Соціальна педагогіка» (Я. Довгополова, О. Мірошник та ін.) - 13.00.08 - «Дошкільна педагогіка» (К. Романюк та ін.), 13.00.02 - «Теорія та методика навчання» (О. Муляр та ін.). У названих роботах увага науковців зосереджена переважно на формуванні толерантності учнівської та студентської молоді у процесі виховної роботи, а також професійній підготовці майбутніх учителів до формування толерантності учнів. Майже кожен автор дослідження впроваджував у практику роботи загальноосвітніх, дошкільних, вищих навчальних закладів програми спецкурсів, курсів за вибором з проблем толерантності.

3-поміж загального масиву дисертаційних досліджень виокремлюємо роботи, що стосуються виховання / формування в учнів / студентів окремих видів толерантності. Це дозволило нам простежити динаміку змін інтересу науковців до певних соціальних сфер прояву толерантності / інтолерантності. Так, у роботах О.Гриви, Т. Гурової, Я. Довгополової, Е. Койкової розглядаються питання формування толерантності молоді в умовах полікультурного простору. Формування міжетнічної та міжнаціональної толерантності досліджено в роботах О. Вербицького, О. Дрозд, І. Залєсової, К. Романюк. У межах досліджень 3 гендерного виховання учнівської молоді захищені дисертації щодо 
формування гендерної толерантності (О. Морозова, С. Фадєєв, Л. Шустова та ін.). Як окремий напрямок педагогічних досліджень визначаємо наукові розвідки 3 проблем толерантності вчителя загальноосвітньої школи (М. Андреєв, Н. Бирко, Т. Білоус, Т. Варенко, І. Залєсова, М. Карандаш, Ю. Котелянець, Р. Костенко, Ю. Тодорцева).

До третьої групи джерел ми віднесли методичну літературу (навчальні посібники, рекомендації, що розроблялися педагогічними колективами закладів освіти різних типів, узагальнення досвіду, звіти, матеріали з'їздів, конференцій).

У методичних рекомендаціях ми мали змогу відстежити практичну сторону втілення ідеології толерантності в освітній процес, тобто реалізацію теоретичних напрацювань науковців, а також простежити найбільш розповсюджені у хронологічних межах дослідження педагогічні ідеї щодо педагогічних технологій виховання толерантності учнівської молоді. Як приклад, відзначимо методичні рекомендації С. Борисюк «Розвиток колективної толерантності та згуртованості засобами групової консультативної роботи», М. Масютіної «Виховуємо толерантність: форми та методи роботи», М. Горват «Виховання толерантності у процесі інтерактивного педагогічного спілкування», А. Зінченко «Педагогіка комунікативної толерантності у вищій школі», І. Тишик «Міжетнічна толерантність як кроскультурна складова педагогічної діяльності викладача історії», Н. Орловської «Школа толерантності: шлях до формування толерантного суспільства». Важко переоцінити значення для нашого дослідження збірників наукових конференцій. Матеріали, опубліковані у збірниках, презентують результати педагогічних пошуків і наукових досліджень з різних напрямків педагогічної науки. Протягом II половини XX-початку XXI століття було проведено велику кількість науково-методичних конференцій, науково-практичних семінарів, педагогічних читань $з$ проблем навчання та виховання учнівської молоді, у ході яких з-поміж інших розглядалися питання толерантності, гуманізму, демократизації освітнього процесу.

Важливими історико-педагогічними джерелами досліджень історії розвитку ідеї толерантності $є$ документи освітніх установ, навчальних закладів та органів народної освіти. Значна частина означених матеріалів зберігається у фондах документів шкіл та органів управління освітою державного та обласних архівів. Матеріали названих установ містять інформацію про практичну реалізацію міжнародних, державних, регіональних нормативних документів у галузі виховної роботи з учнівською молоддю, зокрема 3 питань виховання толерантності.

Отже, у статті здійснено систематизацію джерелознавчої бази досліджень історії розвитку ідеї толерантності у педагогічній думці України на основі інтеграції змісту і виду джерел, що дає змогу розглянути розроблення різних аспектів досліджуваної проблеми в динаміці: від теоретичного обгрунтування до практичної реалізації.

\section{Література}

1. Бардиер Г. Л. Социальная психология толерантности: автореф. дисс. на соискание ученой степени доктора психол. наук: спец. 19.00.05 «Социальная психология»/ Г. Л. Бардиер. - Санкт-Петербург, 2007 - 45 с. 2. Голубнича Л. О. Класифікація джерел історіографії педагогічної персоналії / Л. О. Голубнича // Педагогічний дискурс. - 2013. Вип. 15. - С. 162-167. - Режим доступу: http://nbuv.gov. ua/j-pdf/peddysk_2013_15_35.pdf 3. Гупан Н. М. Українська історіографія історії педагогіки / Н. М. Гупан. - Київ : А.П.Н., 2002. - 224 с. 4. Декларація принципів толерантності, схвалена Генеральною конференцією ЮНЕСКО на 28-й сесії в Парижі 16 листоп. 1995 р. // Віче. - № 11(128). - 2002. - С. 12-13. 5. Калакура Я.С. Історичне джерелознавство: [підручник для студ. іст. спец. вузів]/ Я. С. Калакура, І. Н. Войцехівська, Б. І. Корольов; [та ін.]. - Київ : Либідь, 2003. - 486 с. 6. Коммуникация в современной науке. - Москва : Прогресс, 1976. - 438 с. 7. Лобода С. М. Педагогічна творчість учителя на шпальтах вітчизняної преси ХХ століття: протистояння ідей : [монографія] / С. М. Лобода ; Держ. закл. «Луган. нац. ун-т імені Тараса Шевченка». Луганськ : Вид-во ДЗ «ЛНУ імені Тараса Шевченка», 2010. - 504 с. 8. Петренко О. Б. Гендерні підходи до освіти та виховання в історії вітчизняної школи і педагогіки (XX 
століття) : дис. на здобуття наук. ступеня д-ра пед. наук : спец. 13.00.01 «Загальна педагогіка, історія педагогіки»/ Петренко Оксана Борисівна. - Київ, 2011. - 426 с. 9. Раскин Д. И. Историко-педагогический источник в свете современных проблем источниковедения и системного подхода / Д. И. Раскин // Актуальные вопросы историографии: сб. науч. тр. / Под ред. Э. Д. Днепрова и О. Е. Кошелевой. - Москва: Изд. АПН СССР, 1986. - 230 с. 10. Раскин Д. И. Классификация историко-педагогических источников / Д. И. Раскин // Историографические методологические проблемы изучения истории отечественной школы и педагогики : [сб. науч. тр.] / под ред. Э. Д. Днепрова и О. Е. Кошелевой. - Москва , 1989. С. 85-98. 11. Сейко Н. А. Доброчинність у сфері освіти України (XIX - початок XX століття) : автореф. дис. на здобуття наук. ступеня д-ра пед. наук : спец. 13.00.05 «Соціальна педагогіка» / Н. А. Сейко. - Луганськ, 2009. - 44 с. 12. Сухомлинська О. В. Періодизація педагогічної думки в Україні: кроки до нового виміру / О.В.Сухомлинська // Розвиток педагогічної і психологічної наук в Україні 1992 - 2002. Збірник наукових праць до 10-річчя АПН України. - Частина 1. - Харків : ОВС, 2002. - С. 37-54. 